\title{
The Apache Longbow-Hellfire Missile Test at Yuma Proving Ground: Ecological Risk Assessment for Tracked Vehicle Movement across Desert Pavement
}

\author{
Mark J. Peterson, William W. Hargrove, and Rebecca A. Efroymson \\ Environmental Sciences Division, Oak Ridge National Laboratory (ORNL), \\ Oak Ridge, TN, USA
}

\begin{abstract}
A multiple stressor risk assessment was conducted at Yuma Proving Ground, Arizona, as a demonstration of the Military Ecological Risk Assessment Framework (MERAF). The focus was a testing program at Cibola Range that involved an Apache Longbow helicopter firing Hellfire missiles at moving targets, that is, M60-A1 tanks. This article describes the ecological risk assessment, using the MERAF, for the tracked vehicle movement component of the testing program. The principal stressor associated with tracked vehicle movement was soil disturbance, and a resulting, secondary stressor was hydrological change. Water loss to desert wash vegetation was hypothesized to result from increased infiltration and/or evaporation associated with vehicle disturbances to surrounding desert pavement, potentially affecting mule deer as well as vegetation. The simulated exposure of wash vegetation to water loss was quantified using estimates of disturbed land area from a digital orthogonal quarter quadrangle aerial photo and field observations, a 30-m digital elevation model, the flow accumulation feature of ESRI ArcInfo GIS, and a two-step runoff process dependent on soil characteristics and the extent of disturbance. In all simulated scenarios, the absolute amount of water lost increased with distance from the disturbance downslope in the washes; however, the percentage of water lost was greatest in land areas immediately downslope of a disturbance. Potential effects on growth and survival of desert wash trees were quantified by comparing water availability from the hydrologic model to water volume thresholds required for wash trees to survive and persist, derived from a local study. For both the incremental risk of the test program and for the combination of test and pretest disturbances, this demonstration of MERAF
\end{abstract}

Received 23 January 2008; revised manuscript accepted 11 April 2008.

Current address for William W. Hargrove: Eastern Forest Environmental Threat Assessment Center, Southern Research Station, USDA Forest Service, Asheville, NC 28804-3454, USA.

This article has been authored by a contractor of the U.S. Government under contract DEAC05-00OR22725. Accordingly, the U.S. Government retains a nonexclusive, royalty-free license to publish or reproduce the published form of this contribution, or allow others to do so, for U.S. Government purposes.

Address correspondence to Mark J. Peterson, Environmental Sciences Division, Oak Ridge National Laboratory (ORNL), Oak Ridge, TN 37831-6036, USA. E-mail: petersonmj@ornl.gov 


\section{J. Peterson et al.}

found no significant risk to either wash vegetation growth and survival or mule deer abundance and reproduction.

Key Words: ecological risk assessment, tracked vehicle, desert wash, desert pavement, surface varnish, vegetation, water loss, soil disturbance.

\section{INTRODUCTION}

Evaluations of ecological impacts of military training and testing programs involving vehicles are a common component of U.S. National Environmental Policy Act (NEPA) Environmental Assessments and Environmental Impact Statements (BRACD 2007; YPG 2001), as well as scientific research on military installations. Particularly numerous are studies of tracked vehicle effects on vegetation (e.g., Dale et al. 2005; Haugen et al. 2003; Prosser et al. 2000; Wilson 1988). The impacts of tracked vehicle movement on various fauna and their habitats have also been investigated, including impacts on small mammals (Leis et al. 2007), reptiles and amphibians (Guyer et al. 2006; Adams et al. 2005), bird populations (Severinghaus and Severinghaus 1982), and soil invertebrates (Althoff and Thien 2005). Tracked vehicle disturbances are also commonly evaluated as part of military testing, planning, and predictive models, such as the Ecological Dynamics Simulation Model (EDYS; Childress et al. 1999) and the Army Training and Testing Carrying Capacity (ATTACC) model (USAEC 1999). However, until now, impacts of tracked vehicles and other military activities involving physical stressors have not been investigated through the use of a risk assessment framework.

The U.S. Environmental Protection Agency's (USEPA) Guidelines for Ecological Risk Assessment (1998) were written to apply broadly to any chemical, physical, or biological stressor. The Military Ecological Risk Assessment Framework (MERAF) was developed as an elaboration of the EPA guidelines for multiple military activities (Suter et al. 2002; Efroymson et al. 2001a,b; Efroymson and Suter 2001; Efroymson et al. 2000). This article aims to demonstrate the application of MERAF and to assess the risks associated with tracked vehicle movement on desert wash vegetation and desert mule deer (Odocoileus hemionus crooki) at Yuma Proving Ground (YPG). One of the strengths of MERAF is its ability to characterize the interactions of multiple stressors from a disturbance. This article is one of a series of papers describing an ecological risk assessment for the Apache Longbow-Hellfire missile test at YPG, conducted in August 2000 (see Efroymson et al. 2008a,b and Jones et al. 2008, all this issue). The Apache Longbow-Hellfire missile test and the YPG environment is described in Efroymson et al. (2001b) and Efroymson et al. (2008a, this issue), and includes missile firing and helicopter overflight activities in addition to tracked vehicle activity. The evaluation of tracked vehicle activity was centered on an area adjacent to McAllister Wash within the Cibola Range, in the northwest section of the base, where as part of the test the Apache Longbow helicopter fired Hellfire missiles at moving targets, M60-A1 tanks.

This article presents an application of the MERAF framework to one type of military activity (tracked vehicle disturbance) and includes suggestions for various factors to consider in such an assessment as well as general procedures or approaches that could be used. Any risk assessment, however, depends on the particular 
characteristics of the ecosystem or habitat where the activities occur. Several characteristics relatively unique to the YPG desert ecosystem were relevant for the assessment of risks posed from military testing there and are discussed in the characterization of exposure section of this article.

The most important aspect of the YPG environment for this assessment is the unique nature of "desert pavement" soils, which refers to a continuous, glazed varnish that develops over these soils as a result of prolonged weathering. This aged soil surface at YPG is relatively impermeable to infrequent high-volume rainfall events (Glass 2000; Cochran 1991). A connected aspect of YPG ecology is the desert wash, a lower-lying drainage area that can receive large volumes of flowing surface water from the surrounding impervious rock surfaces and soil pavements. Because of the washes' hydrologic connectivity to larger upslope contributing areas and their increased surface permeability, washes can support larger and more diverse vegetation communities than surrounding areas (YPG 2001; Bern 1995). These desert wash vegetation communities and the wildlife they support thus represent ecologically valuable endpoints for impact assessment. This study integrates the growing field of desert ecohydrology (Hamerlynck et al. 2002; Huxman et al. 2005) with ecological risk assessment.

The evaluation of ecological risks associated with tracked vehicle movement is characterized in this article in the problem formulation, characterization of exposure, characterization of effects, and risk characterization stages of MERAF. For the exposure, effects, and risk characterization stages of this assessment, the findings are organized for (1) vegetation in washes and (2) mule deer.

\section{PROBLEM FORMULATION}

\section{Potential Stressors, Modes of Action, and Conceptual Model}

Stressors and modes of action associated with movement of the target vehicles in the Apache Longbow-Hellfire missile test are listed in Table 1. The stressor that is emphasized in this activity-specific risk assessment is the disturbance of desert pavement, which causes altered hydrology, a secondary stressor. Vibration resulting from tank movement is not considered as a potential stressor here, because the consequences of vibration are largely unknown.

The conceptual model for vehicle movement is depicted in Figure 1. The model represents the combination of stressors associated with vehicle movement in the Apache Longbow-Hellfire missile test, without depicting the importance of each stressor. At YPG the stressor pathway of most importance was deemed to be vehicle movement on soils, which potentially affects hydrology, plant properties and habitat, and ultimately animal populations. The assessment endpoints were the biomass and diversity of desert wash vegetation and abundance and reproduction of the local population of desert mule deer (see general problem formulation in Efroymson $e$ al. 2008a, this issue). Erosion has been linked to tank tracks (Watts 1998), and erosion and plant exposure to eroded soils could be a major component of some MERAF assessments of tracked vehicle movement (Figure 1). Evaluations of exposure and effects of the Apache Longbow-Hellfire missile test include modeled estimates of an actual test in August 2000 as well as reasonable hypothetical scenarios. Fuel leakage, 


\section{J. Peterson et al.}

Table 1. Stressors and modes of action associated with off-road ${ }^{\mathrm{a}}$ tracked vehicle movement.

\begin{tabular}{ll}
\hline Stressor & Potential mode of action \\
\hline Sound of vehicle & $\begin{array}{c}\text { Behavioral response of wildlife, } \\
\text { auditory damage to wildlife, } \\
\text { interference with foraging or } \\
\text { predation, interference with mating } \\
\text { Interference with signaling among } \\
\text { wildlife }\end{array}$ \\
Sound level at a particular frequency & $\begin{array}{c}\text { Crushing of vegetation or wildlife; } \\
\text { disturbance of soil, leading to } \\
\text { changes in vegetation biomass } \\
\text { Physical tank } \\
\text { Toxicity to vegetation or wildlife } \\
\text { Interference with plant } \\
\text { Dust } \\
\text { evapotranspiration, respiratory effect } \\
\text { in wildlife } \\
\text { Altered hydrology, leading to reduced } \\
\text { vegetation biomass, and/or reduced } \\
\text { herbivorous population }\end{array}$ \\
\hline
\end{tabular}

${ }^{a}$ On-road vehicle movement would be expected to generate all of these stressors except for the disturbance of desert pavement.

${ }^{\mathrm{b}}$ No evidence for this effect, and not expected to be observed among mule deer.

crushing, and sound generation were deemed to be less important stressors for this test. There is no pathway for development of trails in wash areas, because vehicle movement in washes is avoided when possible at YPG. However, this pathway is indicated in the model (dashed lines in figure), because vehicle movement in washes may need to be considered in risk assessments of vehicle movement at other military test or training facilities.

\section{Selection of Activity-Specific Measures of Exposure}

Measures of the intensity of disturbance (weight of tank, number of tanks, sound of tanks) were not used because of a lack of test data or an inability to link these measures of intensity to definitive ecological effects. Although tracked vehicles are quite loud during turns, the actual tank noise for this test and resulting ecological effects were deemed to be highly uncertain. Jones et al. (2008, this issue) and Efroymson et al. (2008b) highlight the risk uncertainties associated with noise for the missile firing and helicopter overflight components of the test.

Temporal aspects of exposure include duration, frequency, and timing. The duration and frequency of tank movements can be an important consideration relative to noise effects; however, the duration of tank movements for this test is quite short, and the frequency of such events is low (eight events). An additional temporal measure of exposure is the duration of the disturbance, in this case soil disturbance, prior to recovery to a relatively unimpacted state. Vehicle disturbance zones can last for decades in desert ecosystems (Bolling and Walker 2000), and thus this temporal aspect of exposure is not measurable. The timing of tank noise could be important 


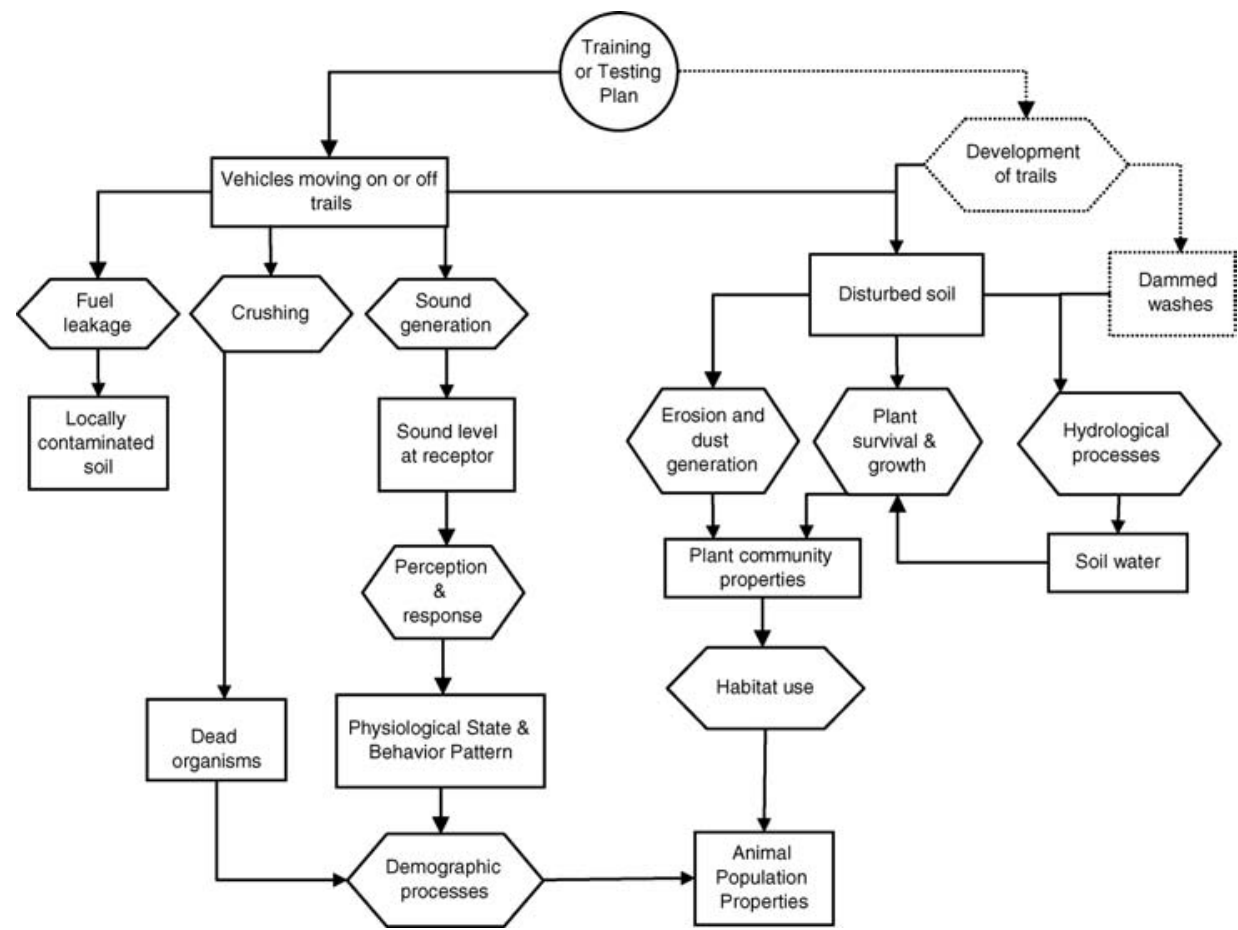

Figure 1. Conceptual model for vehicle movement in Apache Longbow-Hellfire test at Yuma Proving Ground. Dotted line indicates that road development is not part of the Apache-Hellfire test program, but risks from the development of roads or trails could have been integrated with those of vehicle movement. Fuel leakage from tanks is included in the conceptual model but was not deemed to be a significant stressor to plant and animal populations for this test.

to wildlife, particularly as it relates to reproductive behaviors and home range locations. Tank training affects desert pavement, influencing runoff hydrology that could impact wash plant communities in geographically distant washes. Repeated use of already disturbed pavement could exacerbate compaction and ponding of water, but repeated use of disturbed pavement is likely to result in small, incremental hydrological changes relative to effects from initial disturbance of more pristine pavement.

The spatial scope of the risk assessment is described in Efroymson et al. (2008a, this issue), although for the tracked vehicle activity of the test, the downstream desert wash areas are emphasized. The moving targets of the Hellfire missiles (tanks) drove along Moving Target Indicator (MTI) Road before moving off-road and turning around. The extent of spatial disturbance of soil from tracked vehicles and the associated hydrological change are highly dependent on the extent to which tanks drive off-road or on-road. On-road tank tread area would be expected to have minimal incremental impact on compaction of soil or erosion. The off-road tank tread area is a measure of desert pavement disturbance, which is a measure of hydrological change, which 


\section{J. Peterson et al.}

is a measure of changes in wash vegetation. The greater the spatial area of disturbance, the greater the change in surface flows to downslope desert washes and the greater the potential impact to wash vegetation. An example of the use of spatially explicit disturbances as measures of erosion is the use of the ATTACC model, which measures training load in terms of maneuver impact miles (MIM): "One MIM has the equivalent impact on soil erosion as an M1A2 tank driving one mile in an Armor battalion (BN) [field training exercise]" (USAEC 1999).

\section{Selection of Measures of Effects}

The primary measures of the effects of tracked vehicle movement for this assessment relate to the effect of soil disturbance on hydrology, and the effect of changes in hydrology on desert wash plant communities (Figure 1). The primary metrics are estimates of water loss from disturbance in particular soil types and the modeled overall loss of water to the wash vegetation community. Water loss could affect plant biomass or community properties in geographically distant downslope desert washes (the assessment endpoint). Direct measurements of wash plant communities were not conducted as part of this assessment. Few published data are available documenting the direct effect of pavement disturbance on hydrology and wash plant communities. Supporting lines of evidence from other studies in the area and observational information were used as inputs to simulations.

\section{CHARACTERIZATION OF EXPOSURE}

The exposure assessment focused on direct and indirect tracked vehicle stressors on (1) vegetation in washes and (2) mule deer. The primary focus of the characterization of exposure was on the hydrological analysis that modeled tank disturbance of desert pavement and the resultant changes to surface water runoff to wash vegetation.

\section{Vegetation in Washes}

It is assumed for this exposure assessment that desert wash vegetation is not directly exposed to tank track disturbance, such as crushing, dust, or erosion from tanks traveling in washes. Tanks do not travel through washes at YPG, including McAllister Wash, which is the focus of this assessment, based on three lines of evidence: (1) the description of tank training and testing programs by Yuma Proving Ground staff, (2) the lack of visible tank tracks in washes in aerial Digital Orthogonal Quarter Quadrangle (DOQQ) photos of the area, and (3) YPG plant protection policies designed to avoid or minimize disturbance to rare plants, many of which are found in washes. In addition, exposure of wash vegetation to dust was considered negligible because of the distance of the test from washes. Erosion related to the Apache Longbow-Hellfire missile test was also considered negligible, as rain events were extremely rare, and there was little direct evidence of erosion features near locations of tracked vehicle use at YPG. At more vegetated military sites, it is conceivable that tank track area could directly be related to the response of an ecological 
endpoint entity (Ayers 1994). Such exposure could be measured empirically, or estimated using models such as ATTACC.

Indirect exposure and effects to wash vegetation could occur from tank disturbance of desert pavement (primary stressor), resulting in changes in hydrology (secondary stressor) (Figure 1). The impact of soil disturbance on hydrology and vegetation is a key concern in desert environments. Any change to the soil surface in an arid environment can change the hydrology of the soil system, and desert plants are strongly limited by the availability and spatial distribution of soil moisture (Caldwell et al. 2006; Kade and Warren 2002; McAuliffe 1994). At YPG, most of the plant and animal diversity is associated with the desert wash communities (YPG 2001; Bern 1995 ) that rely on surface flow and deep water supply (vadose zone) recharge during seasonal rain events (McDonald 2000). Therefore, soil-water-plant interactions associated with the tracked vehicle component of the Apache-Hellfire test was a major focus of this study.

For most soil types and desert crusts outside of the hyperarid desert, tracked vehicle disturbances related to soil and vegetation compaction would include decreased soil permeability, and increased runoff and erosion due to vehicle disturbance (Ayers 1994; Prose 1985). At YPG, however, the principal mechanism by which desert wash vegetation is impacted in the modeled scenarios is by tank disturbance of desert pavement that results in infiltration and evaporation of water in the resulting ruts and depressions, or upslope of berms along tank tracks, resulting in less surface water runoff to washes (Gilewitch 2004). Depending on a variety of factors including the amount of rain and distance from washes, all trapped water found in depressions in desert pavements might expect to evaporate or infiltrate. Such depressional areas can also create microhabitats for disturbance-adapted plants, potentially resulting in additional water losses via plant retention and transpiration (Kade and Warren 2002). Generally, transpiration loss is minimal in the upland areas because of the general absence of vegetation in desert pavements and mountainous slopes.

For the purposes of the MERAF demonstration, the underlying assumption that tank pavement disturbance limits water runoff to washes was modeled because slope, soil, and desert pavement characteristics of the test area suggested that this scenario was reasonable (McDonald 2000; Ayres Associates 1996), and direct observation indicated drier conditions downslope from roads and water retention at some disturbed sites (e.g., upstream of road crossings, pavement craters; Glass 2000; Bern 1995). In addition, the potential for decreased water flow to desert washes from various disturbances was an interest of natural resource managers at the installation, and the scenario is the most conservative risk assessment approach (i.e., if "sensitive" wash vegetation is impacted, it is likely from water loss, not from too much water to the washes).

\section{Hydrological Analysis Assumptions and Input Variables}

An estimate of tank track area served as an input to the hydrological analysis. Several test and hypothetical vehicle disturbance scenarios were considered. These included pre-existing disturbance, test disturbance plus pre-existing disturbance, a hypothetical scenario of no disturbance, and three hypothetical scenarios involving roadside disturbances (Table 2 ). The latter three scenarios represent allowable, but 


\section{J. Peterson et al.}

Table 2. Vehicle disturbance scenarios for hydrological analysis.

\begin{tabular}{ll}
\hline Scenario & Justification or reference \\
\hline (1) No disturbance & Conditions prior to establishment of test area \\
$\begin{array}{l}\text { (2) Existing disturbance from } \\
\text { previous tests on MTI Road }\end{array}$ & $\begin{array}{c}\text { Disturbance conditions evident from July } 1998 \\
\text { DOQQ image }\end{array}$ \\
$\begin{array}{l}\text { (3) Conservative estimate of } \\
\text { disturbance from Apache }\end{array}$ & Field observations, August 15, 2000 \\
$\begin{array}{l}\text { Longbow-Hellfire test, plus } \\
\text { existing disturbance }\end{array}$ & \\
Hypothetical estimates of 100-m & YPG Aviation and Airdrop Systems had \\
$\quad$ wide roadside disturbances & authorization from the Environment Office to \\
along 900-1000-m sections of: & disturb land up to 100 m on either side of the \\
(4) MTI Road, between West Target & center line of the roads; thus this level of \\
and Red Hill Road & disturbance could have occurred. \\
(5) MTI Road, between Red Hill and & \\
$\quad$ East Target Roads & \\
(6) East Target Road, above West & \\
Target Road & \\
\hline
\end{tabular}

not observed, test disturbances as part of the Apache Longbow-Hellfire missile test. Pre-existing tank track areas were estimated from a 1998 DOQQ aerial photo of the study area (Figure 2). The tank track areas from additional locations of disturbance (an off-road path and tank turnarounds) were estimated from measurements of a single turnaround area during a post-test site visit in fall of 2000 and the assumption that most tank turnarounds are approximately equivalent in size. It was assumed that all or none of each $30 \times 30$-m cell, which is the resolution of the DEM, was disturbed (Figure 3). Thus, disturbances at spatial scales smaller than the majority of a $30 \times$ 30-m cell (about $450 \mathrm{~m}^{2}$ ) were not considered. The estimate of disturbance areas probably represents a conservative (i.e., high) estimate of impacts of the Apache Longbow-Hellfire missile test, because other tests may have been performed in the area between the time of the 1998 DOQQ and the August 2000 test. In future risk assessments, an assessor could use a time series of DOQQs to attribute tank tracks to particular tests, with knowledge of which tests or training programs utilized the site during which period.

To provide estimates of runoff associated with land areas that were disturbed or not disturbed by tracked vehicle movement, this analysis focused on a simulated rainfall event of sufficient intensity and duration to provide runoff to the wash: one inch of rain over a 1-h duration over the entire McAllister and Indian Wash watersheds encompassing the test area. (Indian Wash drains the northwest part of the study area.) Rainfall events of exceptionally high intensity (10- to 100-year return periods) were not considered in this analysis, because much of the water from such an event could not be assimilated by the wash and its vegetation (most of the water would flow downstream out of YPG to the Colorado River), and events of such rarity would not be relevant to plant wash communities in the short term. Based on rainfall distribution calculations used by Ayres Associates (1996) for Yuma Wash (an upland desert wash northwest of the study area), and using rainfall data from Hershfield 

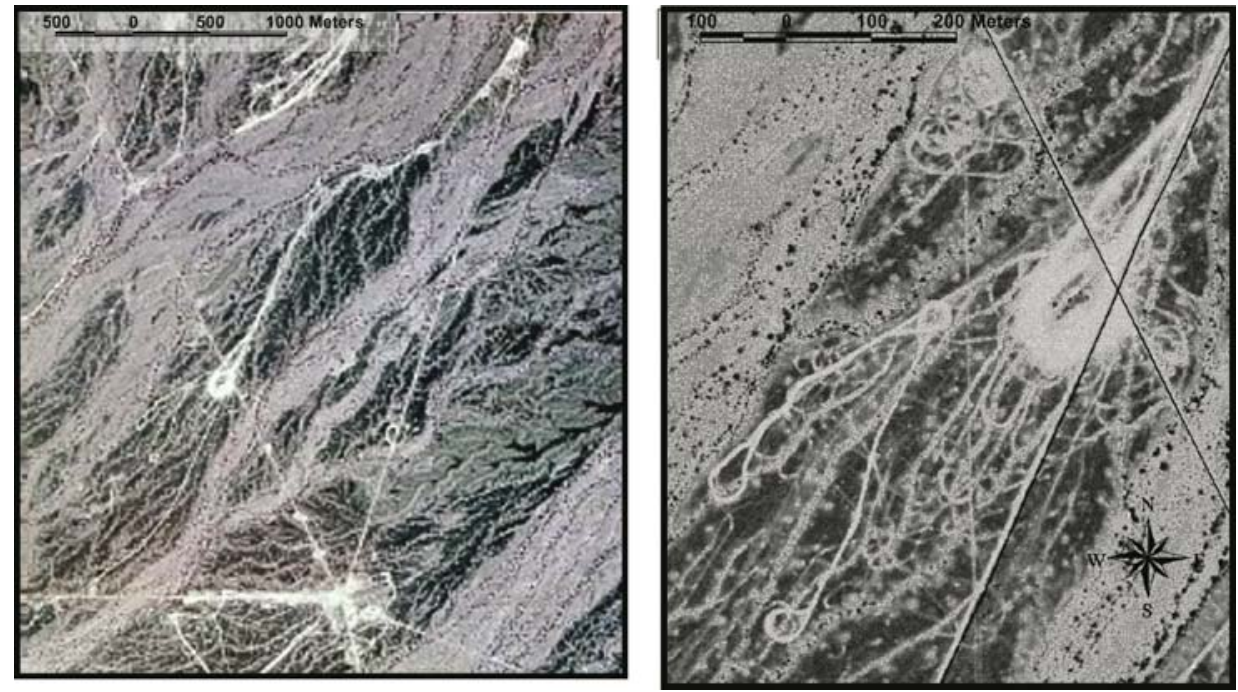

Figure 2. Digital Orthogonal Quarter Quadrangle photos showing examples of tank disturbance along MTI Road and neighboring roads. The right image magnifies the circular (tank turn-around) disturbance from the center-left of the left photo.

(1961), a 1-in rain over a 1-h duration occurring over a watershed over a few square miles would be expected to occur at YPG every three to five years.

The amount of runoff that reaches the desert wash is dependent on rainfall characteristics (e.g., duration, intensity, timing), soil characteristics (e.g., permeability, type of stone cover), vegetation characteristics (e.g., extent and type of vegetation) that affect evapotranspiration, and geomorphological characteristics (e.g., slope, erosion). In the desert of YPG, runoff rarely extends very far because of high transmission loss; that is, reduction of runoff with distance as a result of low rainfall, high evaporation, and infiltration of flow in the wide alluvial channels. Low intensity rains in the winter months provide important direct inputs to desert washes but are unlikely to generate runoff that would provide significant quantities of water to the washes. For this assessment, high intensity, short-duration storms, occurring relatively infrequently in late summer over a multi-year cycle, were deemed to be critical events for runoff-related recharge of the wash water budget (Stromberg et al. 2005).

Because of the proximity of Yuma Wash to the study area and the similarities in soil types and rainfall, many of the same assumptions and input variables used for hydrologic modeling of Yuma Wash (Ayres Associates 1996) were used for this hydrologic assessment. Using the infiltration rates (in/h) of land treatment types presented by Ayres Associates (1996), and adjusting for the different percentages of soil families within each soil complex, infiltration rates were generated for each of the four soil complexes found at the study site (Table 3). The infiltration rates used here are consistent with rates measured for YPG pavement by Glass (2000), 0.9 in $/ \mathrm{h}(2.3 \mathrm{~cm} / \mathrm{h})$, and Musick (1975), $0.39 \mathrm{in} / \mathrm{h}(1 \mathrm{~cm} / \mathrm{h})$. Glass $(2000)$ used for modeling purposes an infiltration rate for desert pavement of $0.4 \mathrm{in} / \mathrm{h}(1 \mathrm{~cm} / \mathrm{h})$, 


\section{J. Peterson et al.}

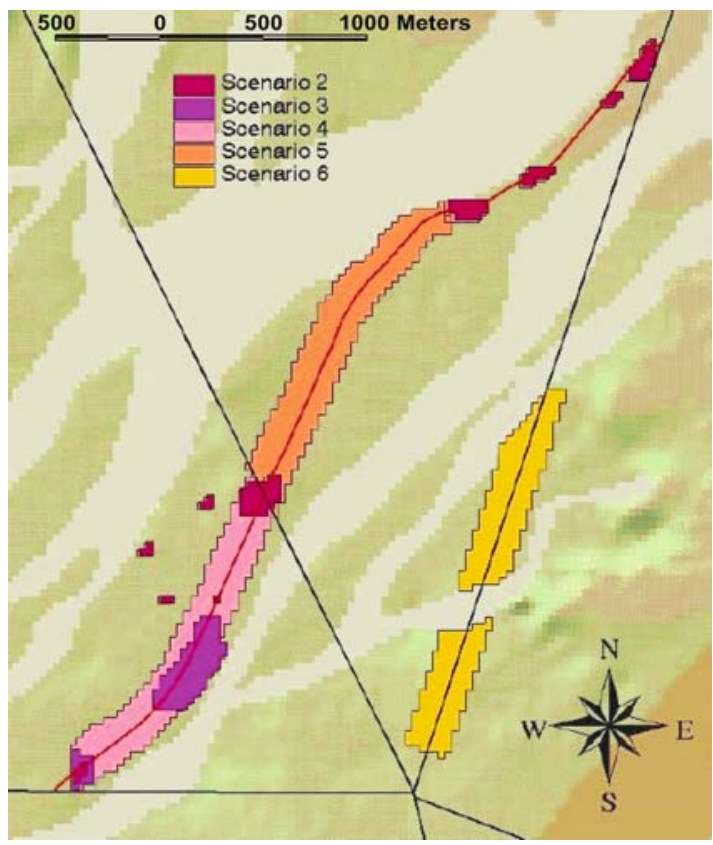

Figure 3. General vehicle disturbance areas for which hydrological change was considered. Six scenarios of differing disturbance were considered. Scenario 1 is no disturbance. Scenario 2 represents existing disturbance from tests on MTI road. Scenario 3 represents a conservative estimate of disturbance from the Apache Longbow-Hellfire missile test, plus existing disturbance. Scenarios 4-6 are hypothetical only and represent different sections of road disturbances that were allowable as part of the Apache Longbow-Hellfire missile test.

which is very close to the value of $0.5 \mathrm{in} / \mathrm{h}(1.3 \mathrm{~cm} / \mathrm{h})$ that was utilized in this assessment (Table 3 ). The delineation of soil complexes was based on soil surveys and mapping by Cochran (1991). General topography and soil complexes in the study area are shown in Figure 4.

Table 3. Infiltration rate in soil complexes in study area at Cibola Range.

\begin{tabular}{|c|c|c|}
\hline Soil complex & $\begin{array}{l}\text { Infiltration } \\
(\mathrm{in} / \mathrm{hr})^{\mathrm{a}}\end{array}$ & Soil and geological characteristics \\
\hline Riverbend family-Carrizo family & 3.0 & $\begin{array}{l}\text { Wash: relatively high permeability, } \\
\text { low runoff }\end{array}$ \\
\hline Cristobal family-Gunsight family & 0.5 & $\begin{array}{l}\text { Pavement: slow permeability, } \\
\text { moderate runoff }\end{array}$ \\
\hline Gunsight family-Chuckwalla family & 0.9 & $\begin{array}{l}\text { Sloping ridge: minor pavement, } \\
\text { moderate-to-rapid runoff }\end{array}$ \\
\hline Lithic and Typic Torriorthents & 0.1 & $\begin{array}{l}\text { Mountainous: low permeability, } \\
\text { rapid runoff }\end{array}$ \\
\hline
\end{tabular}

aNote that the use of an "initial abstraction" term would result in less runoff.

${ }^{\mathrm{b}}$ Based on soil survey descriptions by Cochran (1991). 

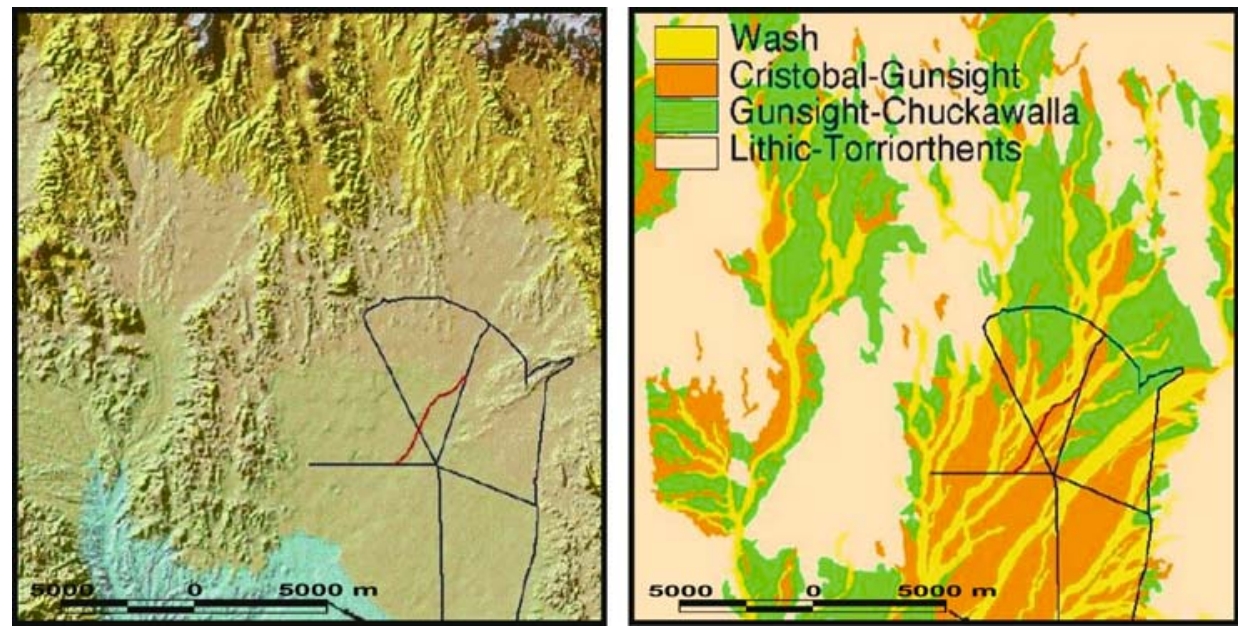

Figure 4. Depiction of general topography using a hill-shaded digital elevation model (left image) and a map of soil complexes delineated by Cochran 1991 (right image) within the Apache-Hellfire test area near MTI road (shown in red). In general, surface runoff flows along McAllister wash (near the MTI road) from high elevation areas to the north and east (upper right in these images) to lower elevation areas to the southwest.

Assuming a 1-in storm event for a 1-h duration, and assuming that water lost to the soil corresponds to the infiltration rates in Table 3 (evapotranspiration processes are not considered in this short-duration storm event), all remaining water is treated as runoff in this hydrologic analysis. This assumption would appear to be reasonable, based on the high percentage of event precipitation falling in the first few minutes of the thunderstorm. Using weighting factors defined by the infiltration characteristics of the soil complexes, two types of proportions were estimated for each $30 \times 30$ $m$ cell in the DEM: (1) proportion of water that runs off of each cell that it lands on directly during precipitation and (2) proportion of water flow that runs off of each cell that it passes by (Table 4). Consequently, infiltration losses first reduce the water directly deposited to the cell, and any remaining infiltration capacity of the soil reduces the runoff passing over the cell from adjacent areas. Runoff from cells is potentially available as moisture for the desert wash vegetation.

The proportion of runoff from disturbed land for the hydrologic simulations was estimated by taking a conservative approach to tank track disturbance (i.e., maximizing the level of water retention associated with disturbed areas). For low-slope, desert pavement (Cristobal and Gunsight family soil complexes), the hydrologic analysis assumes no water leaves the disturbed cell (it infiltrates, ponds, evaporates, or is transpired; Table 4). For more sloping soil complexes such as the Gunsight and Chuckwalla family soil complexes, water retention on disturbed land was deemed to be only slightly more than the undisturbed runoff estimates, and for soil complexes on steep slopes the simulations assumed no additional water retention (Table 4). Glass (2000) reported an average infiltration rate of $0.5 \mathrm{in} / \mathrm{h}(1.3 \mathrm{~cm} / \mathrm{h})$ for various tank track surfaces at a site in the Kofa Range of YPG (east of the study area) 


\section{J. Peterson et al.}

Table 4. Simulated proportions of water that run off of $30 \mathrm{~m}$ by $30 \mathrm{~m}$ land cells during precipitation and overland flow phases. Values for undisturbed land based on infiltration characteristics of soil complexes and slope (Cochran 1991) for the simulated rain event. Conservative estimates of water retention were used for disturbed lands.

\begin{tabular}{|c|c|c|c|}
\hline Process & Soil complex & Undisturbed land & $\begin{array}{l}\text { Disturbed } \\
\text { land }\end{array}$ \\
\hline \multirow{4}{*}{$\begin{array}{l}\text { Direct precipitation } \\
\text { (water directly } \\
\text { deposited to cell) }\end{array}$} & $\begin{array}{l}\text { Riverbend family-Carrizo } \\
\text { family complex }\end{array}$ & $0^{\mathrm{a}}$ & $\mathrm{NA}^{\mathrm{b}}$ \\
\hline & $\begin{array}{l}\text { Cristobal family-Gunsight } \\
\text { family complex }\end{array}$ & 0.5 & 0 \\
\hline & $\begin{array}{l}\text { Gunsight } \\
\text { family-Chuckwalla family } \\
\text { complex }\end{array}$ & 0.1 & 0.05 \\
\hline & $\begin{array}{l}\text { Lithic and Typic } \\
\text { Torriorthents }\end{array}$ & 0.9 & 0.9 \\
\hline \multirow[t]{4}{*}{$\begin{array}{l}\text { Downslope flow } \\
\text { (water passing over } \\
\text { cell) }\end{array}$} & $\begin{array}{l}\text { Riverbend family-Carrizo } \\
\text { family complex }\end{array}$ & $\begin{array}{l}\text { Water entering cell } \\
\text { minus } 2 \text { inches lost by } \\
\text { infiltration }\end{array}$ & $\mathrm{NA}^{\mathrm{b}}$ \\
\hline & $\begin{array}{l}\text { Cristobal family-Gunsight } \\
\text { family complex }\end{array}$ & 1 & 0 \\
\hline & $\begin{array}{l}\text { Gunsight } \\
\text { family-Chuckwalla family } \\
\text { complex }\end{array}$ & 1 & 0.8 \\
\hline & $\begin{array}{l}\text { Lithic and Typic } \\
\text { Torriorthents }\end{array}$ & 1 & 1 \\
\hline
\end{tabular}

${ }^{\mathrm{a}} 1$ indicates that all water leaves cell and is potentially available to lower elevation cells; 0 indicates that no water leaves cell (it infiltrates, ponds, evaporates, or is transpired).

${ }^{\mathrm{b}}$ The value for disturbed soils in the wash community is not applicable for this test and is not applicable to most test programs at YPG, where wash disturbances are avoided where possible.

and $0.7 \mathrm{in} / \mathrm{h}(1.8 \mathrm{~cm} / \mathrm{h})$ in jeep tracks, suggesting that areas of tracked vehicle compaction are not substantially more impervious than desert pavement (and not substantially more likely to increase runoff). Measuring infiltration rates in desert pavements can be difficult, so there is high degree of uncertainty associated with these values (Glass 2000 and P. Haff, Duke University, personal communication, June 12, 2000). Increasing infiltration by loosening of soil by certain kinds of vehicle disturbance, or disturbing the desert soil pavement, is also a possibility in the type of desert environment at YPG (McAuliffe 2007; Gilewitch 2004; Glass 2000). Higher infiltration rates, $2.5 \mathrm{in} / \mathrm{h}(6.4 \mathrm{~cm} / \mathrm{h})$, were observed in creosote bush (Larrea tridentata) mounds that break the pavement surface (Glass 2000), and exploding ordnance produces a similar effect of exposing and loosening fine materials lying below pavement clasts (Efroymson and Suter 2001). Direct measures of ponding, water retention, evaporation, transpiration, and runoff processes were not conducted as part of this hydrological assessment. Future risk assessments of tank disturbance 


\section{Yuma Proving Ground: Ecological Risk Assessment for Tracked Vehicles}

sites at YPG would benefit from using site and test-specific data for calculating water infiltration rates, evaporation, and runoff for various desert soil types.

\section{Implementation of the Spatial Hydrological Model}

The "flow accumulation" feature within ArcInfo was used to provide a spatially explicit assessment of the amount of runoff and water loss in disturbed and undisturbed soils in the study area. This analysis made use of the DEM and estimates of runoff from four soil complexes, under both disturbed and undisturbed conditions. The results of the analyses were maps of net water loss in and downslope from the test area.

The hydrologic analysis occurs on a cell-by-cell basis over the entire study area. First, the flow direction is calculated for each $30 \times 30-\mathrm{m}$ DEM cell. This direction is the single cell of the eight neighbors into which most of the water flows, based on topography. The analysis only considers the maximum or majority flow direction; consequently water flow paths are narrow lines in the simulations (Figure 5), whereas actual flow would be expected to be more widely distributed across space, particularly on relatively flat ground. Then, a flow accumulation analysis is performed, in which the total number of uphill cells contributing water to this cell is tallied. The resulting volume is a crude measure of the total water available to each cell, assuming completely impervious terrain and no water losses (to infiltration, ponding, etc.).

The method for simulating the hydrological effects of desert pavement disturbances resulting from tracked vehicle movement uses a two-step subtraction process that makes use of soil type and infiltration to estimate runoff in disturbed and undisturbed (by tracked vehicles) soils. The two-step method in ArcInfo can best be
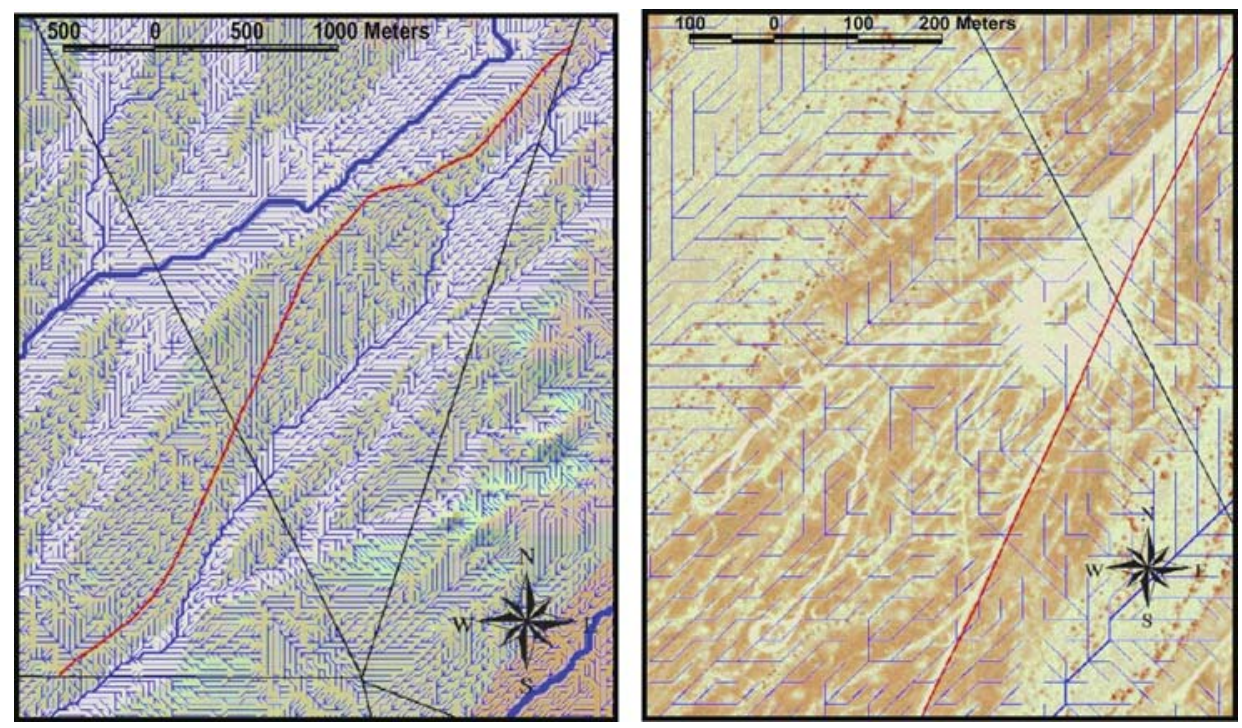

Figure 5. Flow direction lines for the hydrologic analysis conducted within the Apache Longbow-Hellfire test area. The right image provides additional detail from the center-left of the left image. 


\section{J. Peterson et al.}

understood from the perspective of a single map cell. Three hydrological areas are of importance for each cell: (1) the upslope or uphill contributing area from which water flows into this cell; (2) the cell itself; and (3) the downslope or downhill area into which water flows from this cell.

For the flow-accumulation step of the analysis, a runoff weighting grid was devised. This grid consists of numbers between zero and one, representing the estimated proportion of incipient precipitation falling on this cell that was lost to infiltration (Table 4). A unique loss percentage was supplied for each of the four soil types, depending on whether the cell was disturbed or undisturbed. Runoff losses from upslope areas were accounted for in a second, separate subtraction step from the flow accumulation layer. As in the first decrement step, the second subtraction also takes into account the infiltration capacity of the respective soil type and whether the cell is disturbed by tracked vehicles.

After estimating runoff corrected by infiltration losses within every cell, disturbance difference layers were calculated by spatially subtracting runoff estimates of one test scenario from another. The runoff difference layers that result map the reduction in runoff from the differences in disturbance between the two compared scenarios (Figure 6). The spatial subtractions were all ordered so that water flows in the more extensive disturbance scenarios are subtracted from those in the less extreme scenarios. The grids that resulted were converted to vector stream lines using the STREAMLINE command in ArcInfo and were portrayed graphically as streams with increasing width as estimated surface runoff is reduced (Figure 6).

\section{Results of Hydrological Analysis}

Runoff volumes estimated for disturbance associated with tracked vehicles in the test were compared with existing disturbances from tracked vehicle movement on MTI Road. The greatest absolute reductions in runoff occurred in cells far downstream from the spatial locations of the tracked vehicle disturbances (Figure 6). This is largely because decrements to runoff are additive along the downstream flow path. Similar results were obtained when disturbances associated with the Apache-Hellfire test were added to pre-existing disturbances, and compared to hypothetically undisturbed conditions in the test area (Scenario 1, Table 2); that is, the greatest reductions in water volumes were within cells farthest downstream of the test disturbance area.

Potentially more important to herbaceous vegetation than the absolute reduction in runoff, however, is the proportional reduction, that is, the percentage of reduction of inflowing water compared to the total water originally available to plants located in the cell. The proportional water loss associated with the Apache Longbow-Hellfire test scenario (not including pre-existing disturbance), and the proportional water loss associated with a hypothetical disturbance of $100 \mathrm{~m}$ along each site of East Target road (not including the test disturbance or pre-existing conditions), is depicted in Figure 7. The maps of percent loss of water show that the greatest proportional impact occurs in areas just downslope but physically close to the tracked vehicle disturbances from the test, while the proportional water loss is increasingly ameliorated at downslope locations by the contribution of runoff water from additional upslope areas. 

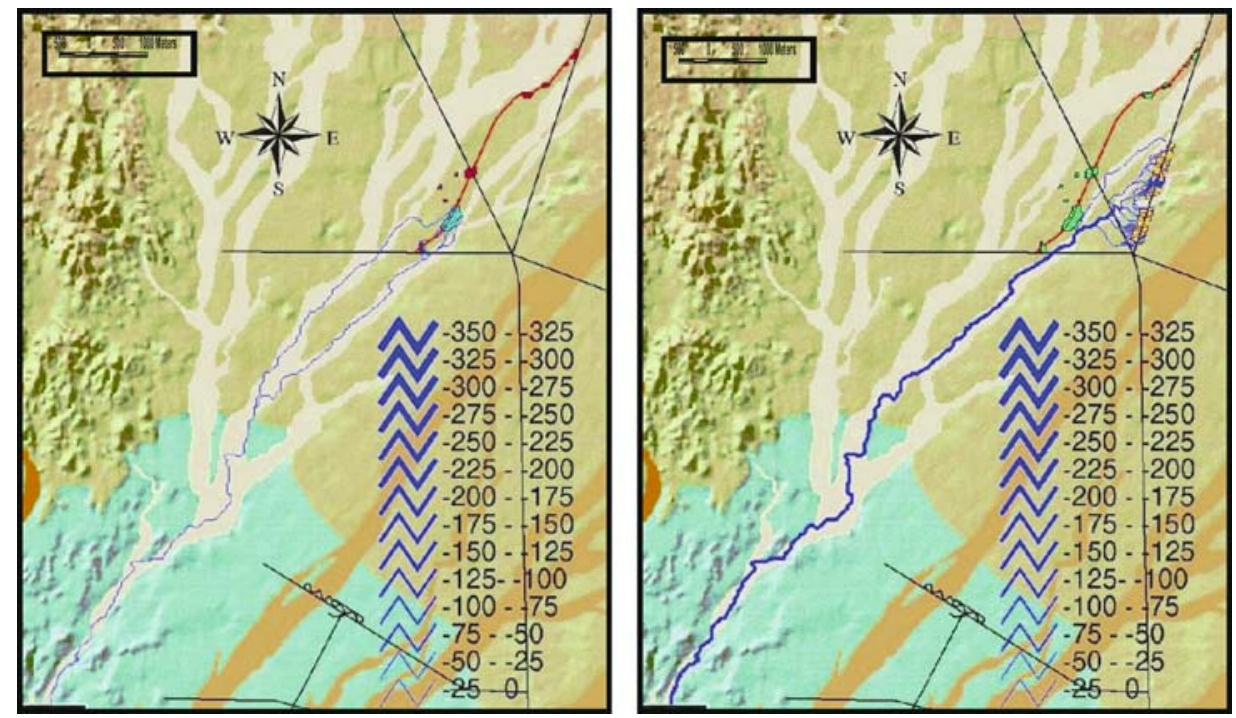

Figure 6. Water loss due to tracked vehicle disturbance associated with the Apache Longbow-Hellfire test (scenario 3 minus scenario 2; left image), in contrast to a hypothetical disturbance of $100 \mathrm{~m}$ along each side of East Target Road (scenario 6 minus scenario 3; right image). The legend signifies the number of cells upgradient of a given cell (adjusted for permeability of cells) from which water no longer flows to the depicted cell; that is, thickness of the stream line represents magnitude of reduction in water volume. There is an incrementally greater reduction of water volume below each juncture of a pair of affected wash tributaries. See Table 2 for scenario descriptions.

\section{Mule Deer}

Mule deer may be exposed directly or indirectly to stressors associated with vehicle movement, such as sound (Figure 1). The sound of the tracked vehicles was not determined. Neither a model nor field data were available. However, tank sound could be locally significant, especially as tanks turn.

The major potential indirect stressor was the reduction in biomass of desert wash vegetation used for forage and cover. Although wash vegetation such as ironwood is a primary forage species for mule deer, significant impacts to vegetation from the test would need to occur to create a food-limited situation. Based on the magnitude of the test and the likelihood of vegetation effects from altered hydrology, mule deer were not likely to have been exposed to reduced vegetation biomass in the washes.

\section{CHARACTERIZATION OF EFFECTS}

\section{Vegetation in Washes}

Exposure-response relationships are models of the induction of effects by exposure to a particular stressor or set of stressors associated with an activity. That is, the 

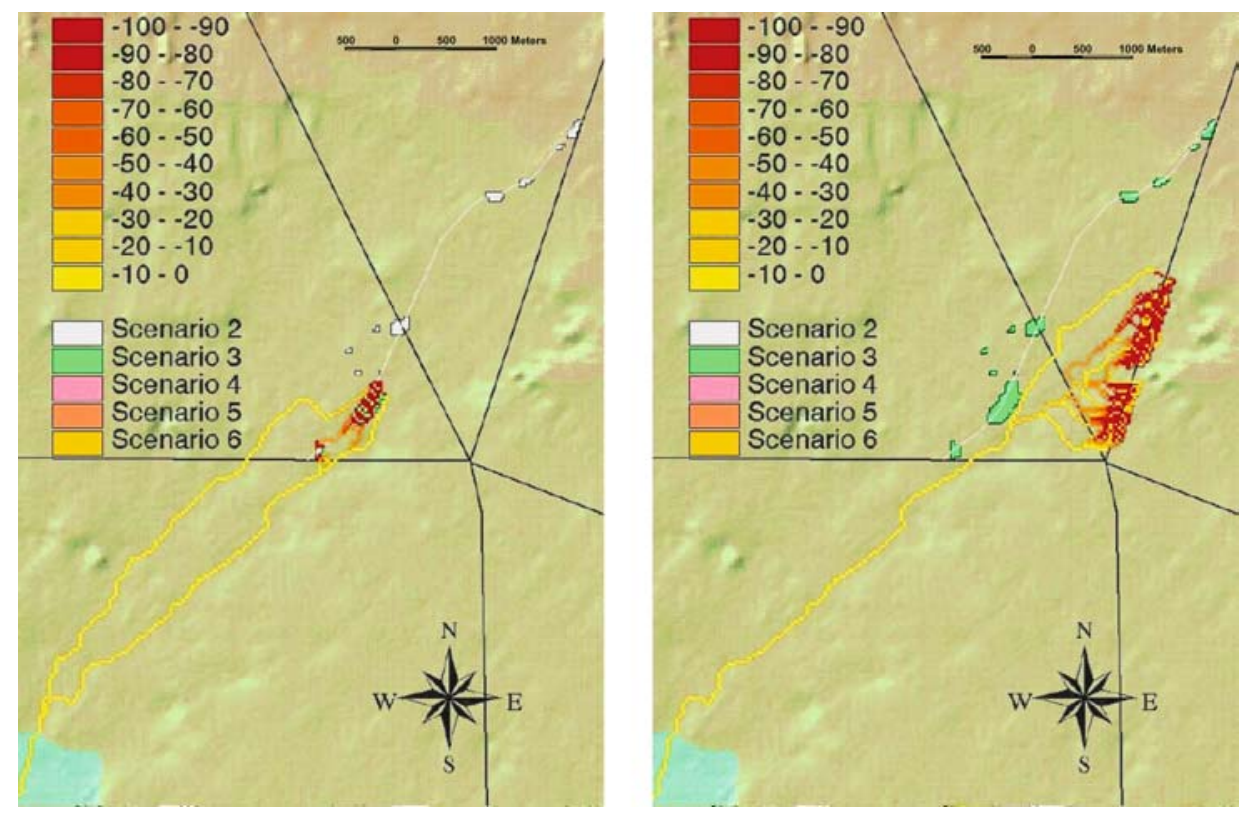

Figure 7. Percent water decrement associated with approximate vehicle disturbance areas from the Apache Longbow-Hellfire test (scenario 3 minus scenario 2; left image). Percent water decrement associated with hypothetical disturbance of $100 \mathrm{~m}$ along each side of East Target Road is also shown for comparison (scenario 6 minus scenario 3; right image). See Table 2 for scenario descriptions.

level of expected effect increases with increasing exposure to the stressor. For many stressors and receptors there is a threshold exposure level below which no consequential effects occur, an increasing level of effects with increasing exposure, and a level at which the maximum effects occur (e.g., extinction or complete denuding of vegetation).

Ideally, direct measurement of changes in vegetation as a consequence of tracked vehicle disturbance before and after the Apache Longbow-Hellfire missile test would be conducted as a line of evidence in the effects (and risk) characterization. However, the natural variability in measures of vegetation that are associated with drought and other environmental influences can be difficult to capture with field plots. For example, in a 72-year study Goldman and Turner (1986) observed that changes in blue palo verde (Parkinsonia floridum) cover over time fluctuated too much for trends to be discerned in 100- $\mathrm{m}^{2}$ plots. Given the high drought tolerance of desert wash vegetation, it may be many years before changes in plant communities can be detected. A vegetation survey was not conducted as part of this study.

The characterization of effects for the assessment of tracked vehicle movement on desert wash vegetation relied on information derived from other studies. YPGspecific studies and observations were found to be the most useful in characterizing effects. Estimates of response thresholds, in this case the volume of water needed for growth and survival of desert wash tree species, were generated using these study 
results. As these thresholds that relate hydrological exposure to plant survival are combined with the results of the hydrologic analysis (i.e., amount of water volume lost due to vehicle disturbance), an approximate estimate of risk can be determined.

\section{Relationships between Surface Hydrology and Vegetation in Washes}

The condition of desert wash vegetation is in large part dependent on the timing and duration of precipitation and associated runoff. Many herbaceous wash species lie dormant as seeds until adequate rain is available for germination and subsequent flowering, which may occur once in several years. Because of the capacity of seeds to remain viable over a decade or longer, the long-term effects of low moisture on herbaceous plant populations are extremely difficult to measure. The moisture stress of arid woody shrub and tree species is also difficult to evaluate. Short-term impacts from drought may be measurable in individuals (e.g., loss of leaves, presence of standing snags, low growth) but may not indicate community-level impacts over the long term. Interpretation of community-level metrics is also complicated by the spatial variation of wash species. For example, locally significant desert wash tree species such as palo verde, ironwood (Olneya tesota), catclaw acacia (Acacia greggi), and smoketree (Psorothamnus spinosa) are adapted to low moisture regimes, and populations may expand or contract with the changing channel and shifting of alluvial deposits typical of wash soil dynamics.

Schlesinger and Jones (1984) (as reported in Schlesinger et al. 1989) showed that diversion of overland flow from alluvial piedmonts resulted in lower shrub density and biomass compared to that in adjacent areas that received overland flow. At YPG, water available to desert wash tree species is presumably dependent on adequate runoff from the adjacent desert pavements during storm events. Pavement disturbances that affect runoff to the washes have the potential to affect the quality and quantity of wash vegetation, thereby affecting wildlife that utilize this vegetation.

McDonald (2000) studied the relationship between surface and soil moisture and desert shrubs and trees at YPG. Spring and mid-summer predawn and midday water potentials achieved in palo verde and ironwood are much higher than would be expected, given the very low volumetric moisture content of the soils $(<1 \mathrm{~m})$. McDonald suggests that these species have access to deeper water supplies (2-6 m, vadose zone, not groundwater). His preliminary results indicate that infrequent, high energy storms may be necessary to create enough overland runoff to recharge deeper soil depths in the wash. These deeper water supplies may help sustain wash plant activity over prolonged dry periods ( $>1$ to 3 years), where direct precipitation may be insufficient to recharge shallower surface layers.

Ayres Associates (1996) identified changes in hydrologic processes from historical military disturbances as a major factor affecting vegetation in Yuma Wash, although specific changes in vegetation metrics as a result of changes in water volumes were not quantified. As part of the Land Condition Trend Analysis program at YPG (Bern 1995), the number of ironwood and palo verde were counted "upstream" and "downstream" of Pole Line Road in the Kofa Range, and the number of plants were reduced downstream (4 compared to 20 upstream), presumably due to changes in hydrology from the road crossing of the wash (Bern 1995). The number of dead plants was also twice as high on the downstream plot. Reductions in plant biomass below road 


\section{J. Peterson et al.}

crossings, where the road was sufficiently elevated over the surrounding landscape, were also observed by the MERAF team.

Glass (2000) investigated the relationship between disturbance in hydrology and channel vegetation in a very small, undisturbed watershed $\left(0.2 \mathrm{~km}^{2}\right)$ in the Kofa Range of YPG. Results show that for a $20 \%$ increase in infiltration depth, the percentage of the total gully length no longer supporting wash trees increases between $6 \%$ and $18 \%$. Although the vegetation measures conducted for the Glass (2000) study do not represent a detailed botanical assessment, the study nevertheless provides useful YPG-specific information for making a more quantitative link between water loss due to disturbance and changes in vegetation. This Masters Thesis study was used extensively for the characterization of effects and risk characterization stages of this risk assessment.

\section{Physiological Water Requirements of Desert Wash Species}

Data on the specific water requirements of tree and shrub species in the study area, in terms of volume of water, were not readily available in the literature. Clearly, wash shrub and tree species, by the nature of their presence in washes and absence in more upland areas, have higher water requirements than the more abundant species found at YPG [such as white bursage (Ambrosia dumosa) and creosote bush]. Using water potential from various literature sources as an index for how much water a plant requires, Glass (2000) ranked four desert plant species in the following order for water need (reported water potentials in parentheses): ironwood (-22 to -35 bars) $>$ foothill palo verde $(-36$ bars $)>$ brittlebush $(-37$ bars $)>\operatorname{creosote}(-40$ to -60 bars). Glass (2000) also measured vegetation frequencies of these species in two gullies within YPG, and these results correlate with the water potential data: creosote and brittlebush are the first to appear in the upper section of the gully, followed by palo verde, then ironwood.

\section{Determination of Water Volume Thresholds for Wash Trees}

The relationship between contributing area runoff and vegetation observed in gullies in the Kofa Range of YPG by Glass (2000) was used to estimate the volume of water needed for growth and survival of desert wash tree species. Glass assumed that the position and size of the species in a gully was an indicator of water requirement; that is, plants grew to their maximum potential height and biomass in each wash, and plants with greater water need would require greater runoff contributing area, and would be located further downstream. This general finding was common at YPG; for example, ironwood trees at YPG tend to be two to four meters tall at the tops of first order flues, and they become increasingly larger with increasing hydrologic order of the wash.

The Glass (2000) study area was similar to the Apache-Hellfire test area, although the study was of much smaller scale with a focus on relatively narrow gullies, relative to the wide, braided channels of the test area. The Glass (2000) study area was dominated by pavement with little or no vegetation, dissected by gullies where plants with higher moisture requirements predominated. Gully infiltration rates were similarly high as those in McAllister Wash, and the surrounding pavement had low infiltration rates. Glass (2000) cited the similarity of the site on Kofa Range to many areas of 


\section{Yuma Proving Ground: Ecological Risk Assessment for Tracked Vehicles}

YPG and particularly mentioned its relevance to an adjacent watershed where Pole Line Road crosses the wash, resulting in dead and dying ironwood trees downstream of the crossing.

Glass (2000) studied three subbasins, each with two to six individual gullies where the number of individuals of ironwood and palo verde species were recorded at select intervals over the entire length of each gully. Of importance in the analysis was the most upstream location in each gully of an individual plant of ironwood and palo verde. Assuming the first location of ironwood or palo verde in each basin represents the limit of the species' water requirements (upstream of the location the species would not have enough water to survive, downstream it would), the associated water volume running over and into the soil is the minimal volume required for the plant to survive. Discharge volume $(\mathrm{V})$ was calculated as $(\mathrm{P}-\mathrm{I}) \times \mathrm{A}$, where $\mathrm{P}$ is precipitation, $\mathrm{I}$ is infiltration, $\mathrm{A}$ is contributing area, and $\mathrm{V}$ is discharge volume. The Glass (2000) simulations used a 0.03-m storm (1.2 in) for a 1-h duration (a once every 5 -year event), and an infiltration rate of $0.01-\mathrm{m}(0.4 \mathrm{in})$ for the surrounding pavement, to calculate discharge volumes at various points within each sub-basin (similar to the assumptions in this article's hydrological analysis).

Results from Glass (2000) were deemed the best available for the basis of an exposure-response relationship for water volume and wash vegetation. Glass concluded that the volume of water needed in the simulated event for ironwood and palo verde survival ranges from 150 to $350 \mathrm{~m}^{3}$ with an average of $250 \mathrm{~m}^{3}$. This is the survival effects threshold for trees in an approximately 5-m-wide gully. A conversion factor of 6 was used to calculate a volume of water needed for survival of wash trees for each $30 \times 30-\mathrm{m}$ cell in this article's hydrologic model $\left(1500 \mathrm{~m}^{3}\right)$ because of the factor-of- 6 greater width. Differences between lengths of gullies and cells comprising the desert washes were not considered significant determinants of runoff water volumes.

Glass (2000) also measured the sizes of ironwood and palo verde trees, and classified them as small $(<2 \mathrm{~m})$, medium $(2-4 \mathrm{~m})$, and large $(5-7 \mathrm{~m})$. A pattern was observed of small individuals near the top of the gully, and increased numbers and sizes of individuals with distance downstream. A growth effects threshold was estimated by determining the point where large trees were first observed, assuming that smaller individuals represent stressed (or water-challenged) individuals. Large ironwoods are important for wildlife cover, and large trees may be important for successful propagation of the ironwood species. Glass (2000) reported the first downstream location of large trees was approximately 100 to $300 \mathrm{~m}$ farther downstream than the first small tree in three representative gullies. Distances between small and large trees were not measured at YPG, but we assumed that $220 \mathrm{~m}$ was the distance between first small and first large trees, as determined from graphs presented in Glass (2000).

Using slopes for the three gullies relating distance downstream $(\mathrm{m})$ to discharge volume $\left(\mathrm{m}^{3}\right)$, an average discharge volume of $987 \mathrm{~m}^{3}$ was needed for "growth" of wash trees. Using the $6 \times$ conversion factor as explained earlier, the volume of water needed for adequate "growth" of wash trees for each cell in the YPG MERAF hydrologic model was calculated as $5900 \mathrm{~m}^{3}$.

The $1500 \mathrm{~m}^{3}$ water threshold associated with survival and the $5900 \mathrm{~m}^{3}$ threshold of water associated with growth of desert wash trees during the modeled storm 


\section{J. Peterson et al.}

event should not be considered physiological water requirements. Far more water permeates the soil and runs overland than is needed for plant growth. The values are more representative of watershed areas, and the amount of water that permeates soil without evaporating or leaching appreciably (plant-available water) is assumed to approximate physiological water requirements.

\section{Timing of Precipitation}

The timing of precipitation was not explicitly included in the exposure-response relationship derived for the YPG risk assessment; however, the timing of precipitation is important to plant biomass in desert ecosystems. Factors include rainfall during periods when high temperatures cause large losses via evapotranspiration, rainfall during periods when plants are in a state of high temperature dormancy, high intensity rainfall where runoff is considerable, and cool spring temperatures that decrease evapotranspiration, permitting more soil moisture to be utilized in transpiration.

\section{Mule Deer}

A relationship between desert wash vegetation and mule deer populations was not determined for this test case, because there was no significant exposure to deer based on the findings for vegetation. If the exposure had been found to be significant, a relationship between mule deer reproduction, foraging and habitat could have been developed through the use of a mechanistic model. Such a model could include the potential for reduction of forage (e.g., reduction in biomass or change in duration of leaf-on period), change in forage quality, or change in cover quality, leading to an alteration of the deer diet, home range, and/or likelihood of predation (Figure 8). For example, Schmitz (1992) developed a foraging model for white-tailed deer (Odocoileus virginianus) to predict the diet selection when deer face starvation risks during a reproductive period.

\section{RISK CHARACTERIZATION}

\section{Vegetation in Washes}

The amount of water needed in the modeled storm event for survival and growth of key wash tree species was $1500 \mathrm{~m}^{3}$ and $5900 \mathrm{~m}^{3}$, respectively, and these values represent the selected thresholds for assessment of vegetation effects. Areas of McAllister Wash that have adequate quantities of water to support the growth and survival of wash tree species, in the absence of any disturbance, according to this analysis, are shown in Figure 9. When undisturbed, the main wash channels have adequate water for growth and survival of trees, and areas of the washes where growth is affected tend to be located in the upstream sections of the tributaries. The results of this analysis are consistent with field observations and available literature describing the relationship between hydrology and wash tree populations.

Based on the results of the hydrologic analysis, tank disturbance of desert pavements in the Apache Longbow-Hellfire missile test is predicted to result in water losses to McAllister Wash and tributaries, with the greatest percentage of water loss 


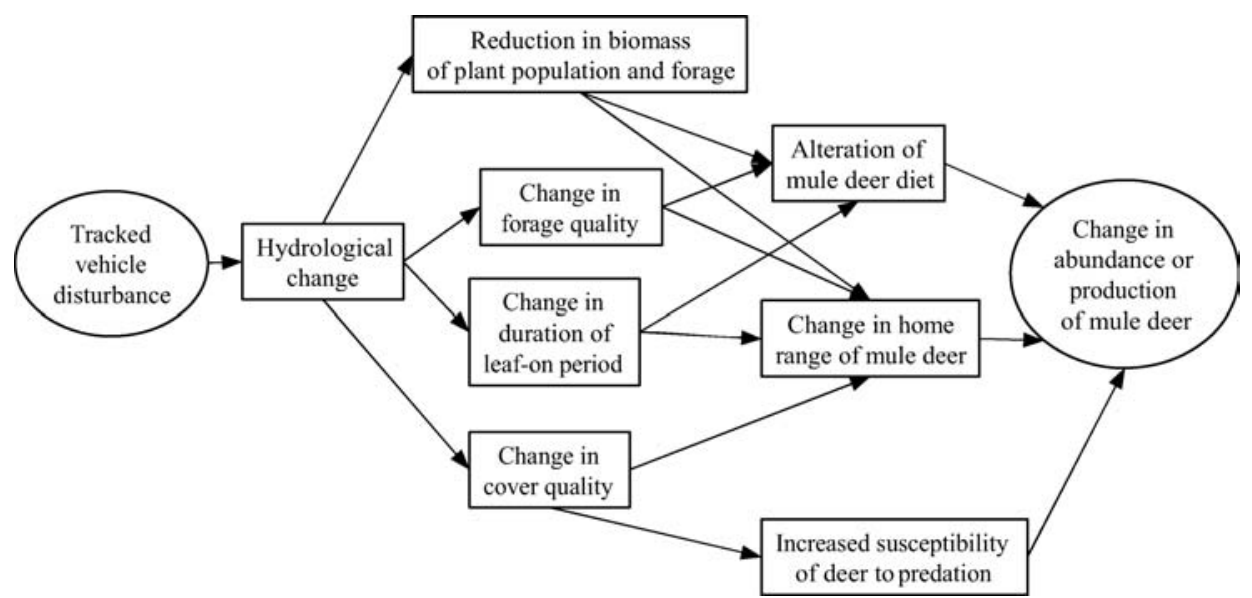

Figure 8. Mechanisms by which tracked vehicle disturbance could affect hydrology, the quality and quantity of vegetation, and abundance or production of mule deer.

occurring nearest the area of disturbance (Figure 7). The predicted amount of water lost as a result of tracked vehicle disturbance, relative to the amount of water under pretest conditions, was compared to the selected water discharge volume thresholds for survival of wash trees, $1500 \mathrm{~m}^{3}$, and growth of wash trees, $5900 \mathrm{~m}^{3}$. This comparison revealed that tracked vehicle disturbance from the test is not expected to result in enough water loss to the desert washes to affect the survival or growth of desert wash
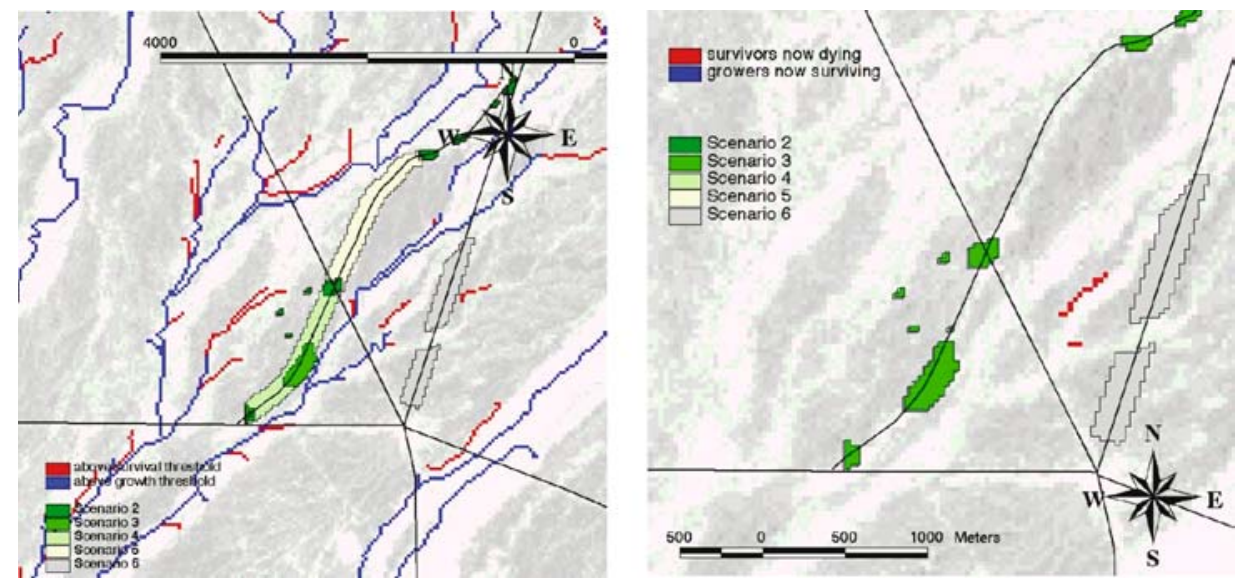

Figure 9. Available water in the model was compared with a survival threshold $\left(1500 \mathrm{~m}^{3}\right)$ and a growth threshold $\left(5900 \mathrm{~m}^{3}\right)$ to produce the map on left showing areas predicted to have enough water for tree survival and growth (without disturbance), and areas where trees were predicted not to have enough water for survival or growth assuming the hypothetical scenario 6 disturbance of East Target Road (map on right). Desert washes appear as lighter areas in the Landsat 7 background image on these maps. 


\section{J. Peterson et al.}

trees (Table 5). In addition, when test disturbances and pre-existing disturbance from tests on MTI Road were compared to the undisturbed condition, there was less water moving to the wash, but no additional areas during the Apache-Hellfire test were expected to prevent survival or growth of desert wash trees.

For the three hypothetical scenarios that represented allowable, additional roadside disturbances in the test (Figure 3, Table 2), the larger areas of disturbance were associated with larger quantities of water loss. The risk characterization for these hypothetical disturbance scenarios indicated that wash tree growth or survival could be inhibited in an area as large as $13,500 \mathrm{~m}^{2}$ for a scenario involving disturbance of East Target Road and MTI Road (Table 2; Figure 9). In general, the area of risk to vegetation in washes is predicted to be quite small, even in these hypothetical scenarios that involve a relatively large disturbance area (generally $1000 \times 200 \mathrm{~m}$ roadside disturbance areas).

\section{Mule Deer}

There was no calculated risk to the mule deer population from tank tracks associated with the Apache-Hellfire test, because no appreciable loss of wash vegetation biomass was predicted. The density of deer in this area was assumed to be 0.56 deer per $\mathrm{km}^{2}$ (or one deer per 179,000 $\mathrm{m}^{2}$ ) (Efroymson et al. 2008a, this issue), so even a loss of deer proportional to the area showing loss of vegetation would result in no deer being lost.

\section{RESEARCH NEEDS AND UNCERTAINTY}

Several research gaps exist in the risk pathway from tracked vehicle disturbance to hydrological change to survival and growth of wash vegetation to abundance of mule deer. Soil-water-vegetation processes in desert environments are complex (Ludwig et al. 2005; Lathrop 1993), and the degree to which vehicle-disturbed desert pavements impact hydrology and vegetation at the study location is largely unknown. Sonoran Desert pavement infiltration properties are clearly important in funneling water to wash communities (McAuliffe 2007), but the characteristics of desert pavements and desert varnishes relative to hydrologic processes are highly varied (McAuliffe 2007; Belnap 2006; Belnap et al. 2005).

A GIS-based hydrological analysis is just one option for evaluating hydrological changes as a result of land disturbance-a number of existing models could be used or expanded to evaluate hydrologic change and potential ecological effects. Mechanistic models exist that can estimate soil-water balance in desert ecosystems (Huxman et al. 2005; McDonald et al. 1996), although few models consider the movement of water overland from one land area to another. Ayres Associates (1996), in modeling hydrology in Yuma Wash, used HEC-1, a computer program developed by the U.S. Army Corps of Engineers Hydrologic Engineering Center (USACOE 1990), and a modified version of The Hydrologic Model (HYMO) computer program developed by the USDA Agricultural Research Service. The Ecological Dynamics Simulation model (EDYS) is another mechanistic model that has been used in a wide range of applications, including ecological risk assessment on Army lands (Childress et al. 1999). Finally, mechanistic demographic or energy balance models could be 


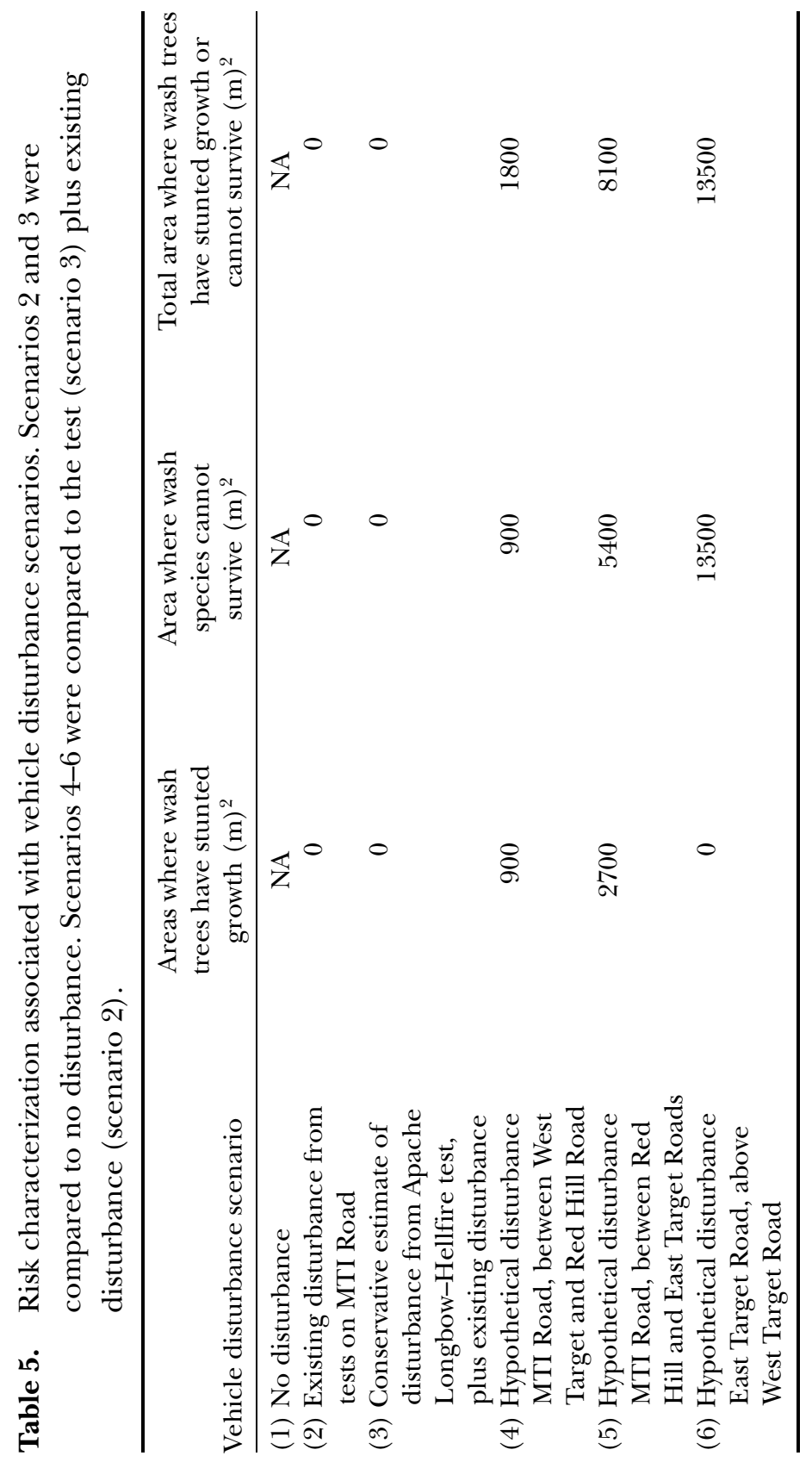




\section{J. Peterson et al.}

developed for key vertebrate species that are prevalent at multiple installations. In some cases, ranges of input parameters might be available to contribute to a quantitative uncertainty analysis.

A formal uncertainty analysis was not conducted for this risk characterization, but sources of uncertainty and variability are described in both the problem formulation and characterization of effects stages of the risk assessment. Key assumptions relate to quantities of water assumed in this assessment: the amount of precipitation, the amount of infiltration, and the amount of overland flow in the hydrologic model associated with particular soil types or disturbance. Conservative assumptions were used in the absence of local data for this risk assessment, but empirical studies could be performed to relate particular types and intensities of disturbance (e.g., disturbance by $\mathrm{X}$ number of tanks of Yweight and $\mathrm{Z}$ track width on pavement or other soils) to water infiltration, runoff, and other changes in hydrology. The cause-effect relationship between water and plant growth and survival should also be validated, as should the importance of particular intensities and durations of precipitation events on disturbance-impacted vegetation growth.

\section{CONGLUSIONS}

This article demonstrates the use of MERAF for tracked vehicle activity, including defining a conceptual model for this type of assessment, potential analysis tools and approaches that could be used (e.g., hydrologic and mechanistic models), and future research needs. This article also presents a highly site-specific example of the use of MERAF, focused on the ecological risks associated with one Apache LongbowHellfire Missile test activity in the rather unique desert environment of YPG. The absence of significant risk to desert wash vegetation and mule deer reflects not only the small spatial and temporal scale of the test activity, but also the absence of sensitive vegetation and wildlife directly impacted by the test disturbances. Pretest planning and range management controls were also a factor, in that test activities in ecologically sensitive wash communities were avoided, and there were established limits to tank movement for the test.

Given that various conservative assumptions were used, this risk assessment provides reasonable assurance to Department of Defense resource managers that individual, small-scale tracked vehicle disturbances in desert pavements at YPG that are similar to those from the Apache-Longbow missile test are unlikely to significantly reduce water runoff to desert wash vegetation downslope of the vehicle disturbance. Logically, future risk assessments must consider site and test-specific conditions, as well as cumulative risk. For this assessment, some wash vegetation impacts could be expected if the vehicle disturbance was substantially larger in scale or more intrusive, although even in the hypothetical scenario with the greatest area of disturbance, the relative impacts to wash vegetation were small.

This risk assessment outlines a reasonable conceptual model and one type of hydrologic approach for evaluating the effects of tracked vehicles on water runoff over desert pavements and associated vegetation and wildlife. Other arid ecosystems that have desert pavements whose principal response to disturbance is an increase in local permeability might benefit from a similar conceptual approach to that employed 
here. Indeed, risk to any system whose main response to disturbance is a significant change in infiltration (either increased or decreased) might be subjected to such an approach. Risk from new building and parking lot construction within urban systems, for example, results in the addition of impermeable surface and might be amenable to such a semiquantitative risk assessment. The common response characteristics shared across such systems is that hydrologic consequences of a disturbance are realized as effects localized in spatially removed downslope areas. The magnitude of such disturbances are spatially concentrated and amplified with downslope distance, while the proportion of the hydrological change is greatest in the downslope areas immediately adjacent to the disturbance.

\section{ACKNOWLEDGEMENTS}

This research was funded by a contract from the U.S. Department of Defense Strategic Environmental Research and Development Program (SERDP) project CS1054, A Risk Assessment Framework for Natural Resources on Military Training and Testing Lands, to Oak Ridge National Laboratory, which is managed by UT-Battelle, LLC, for the U.S. Department of Energy under contract DE-AC05-00OR22725. We thank Bob Holst and John Hall for serving as project sponsors. We also acknowledge the contributions of the following people for data, guidance, manuals, programming advice, text reviews, activity descriptions, and other assistance: Valerie Morrill, Chuck Botdorf, and Junior Kerns from the Yuma Proving Ground Environmental Sciences Division; Sergio Obregon, David McIntyre, and Bruce Goff from Jason \& Associates, Yuma Proving Ground Office; Rick Douglas and Bert Evans from Yuma Proving Ground Aviation and Airdrop Systems; Dick Gebhart and Kim Majerus from the U.S. Army Corps of Engineers Construction Engineering Research Laboratory; and Todd Kuiken, Robert Washington-Allen, and S. Marshall Adams from Oak Ridge National Laboratory. Lastly, we acknowledge and thank the many people who conducted and reported field study results at YPG, without which we would not have been able to conduct this risk assessment.

\section{REFERENCES}

Adams SM, Peterson MJ, Hewitt AJ, et al. 2005. Assessing the Health and Fitness of TES on Military Ranges: Importance of Incorporating Integrated Chemical and Habitat Characterization Studies in Experimental Designs. SERDP Partners in Environmental Technology Technical Symposium and Workshop, November 29 to December 1, 2005, Washington, DC, USA

Althoff PS and Thien SJ. 2005. Impact of M1A1 main battle tank disturbance on soil quality, invertebrates, and vegetation characteristics. J Terramech 42:159-76

Ayers PD. 1994. Environmental damage from tracked vehicle operation. J Terramech 31(3):173-83

Ayres Associates. 1996. Geomorphic, Hydrologic, and Vegetation Characterization and Baseline Conditions, of Yuma Wash, Yuma Proving Ground, Arizona. Final Report. Ayres Project No. 92-0904.01

BelnapJ. 2006. The potential roles of biological soil crusts in dryland hydrologic cycles. Hydrol Process 20:3159-78 


\section{J. Peterson et al.}

Belnap J, Welter JR, Grimm NB, et al. 2005. Linkages between microbial and hydrologic processes in arid and semiarid watersheds. Ecology 86(2):298-07

Bern CM. 1995. Land Condition Trend Analysis Installation Report. Yuma Proving Ground, Arizona, 1991-1994. Center for Ecological Management of Military Lands, Colorado State University, Fort Collins, CO, USA

Bolling JD and Walker LR. 2000. Plant and soil recovery along a series of abandoned desert roads. J Arid Environ 46:1-24

BRACD (U.S. Army Base Realignment and Closure Division). 2007. Available at http://www.hqda.army.mil/acsim/brac/braco.htm. Accessed August 25, 2007

Caldwell TG, McDonald EV, and Young MH. 2006. Soil disturbance and hydrologic response at the National Training Center, Ft. Irwin, California. J Arid Environ 67(3):456-72

Childress WM, Price DL, Coldren CL, et al. 1999. A Functional Description of the Ecological Dynamics Simulation Model, with Applications for Army and Other Federal Land Managers. SMI Technical Report SMI-ES-009. USACERL Technical Report 99/DRAFT 1999

Cochran CC. 1991. Soil Survey of the U.S. Army Yuma Proving Ground, Arizona-Parts of LaPaz and Yuma Counties. US Department of Agriculture, Soil Conservation Service, Washington, DC, USA

Dale VH, Druckenbrod D, Baskaran L, et al. 2005. Vehicle impacts on the environment at different spatial scales: Observations in west central Georgia, USA.J Terramech 4:383-402

Efroymson RA and Suter II GW. 2001. Ecological risk assessment framework for low-altitude aircraft overflights: II. Estimating effects on wildlife. Risk Anal 21:263-74

Efroymson RA, Rose WH, Nemeth S, et al. 2000. Ecological Risk Assessment Framework for Low-altitude Overflights by Fixed-wing and Rotary-wing Military Aircraft, ORNL/TM2000/289. Oak Ridge National Laboratory, Oak Ridge, TN, USA

Efroymson RA, Suter II GW, Rose WH, et al. 2001a. Ecological risk assessment framework for low-altitude aircraft overflights: I. Planning the analysis and estimating exposure. Risk Anal 21:251-62

Efroymson RA, Hargrove WW, Peterson MJ, et al. 2001b. Demonstration of the Military Ecological Risk Assessment Framework (MERAF): Apache-Longbow-Hellfire Missile Test at Yuma Proving Ground. ORNL/TM-2001/211. Oak Ridge National Laboratory, Oak Ridge, TN, USA

Efroymson RA, Peterson MJ, Jones DS, et al. 2008a. The Apache Longbow-Hellfire missile test at Yuma Proving Ground: Introduction and problem formulation for a multiple stressor risk assessment. Hum Ecol Risk Assess (in press)

Efroymson RA, Hargrove WW, and Suter GW. 2008b. The Apache Longbow-Hellfire missile test at Yuma Proving Ground: Ecological risk assessment for helicopter overflight. Hum Ecol Risk Assess (in press)

Gilewitch DA. 2004. The effect of Military Operation on Desert Pavement. A case study from Butler Pass, AZ (USA). In: Caldwell DR, Ehlen J, and Harmon RS (eds), Studies in Military Geography and Geology, Chapter 19. Springer, The Netherlands, 243-258

Glass LS. 2000. Indexing Gully Discharge Deficit to Modifications of Interfluve Properties on Desert Pavement Fans and Implications for Gully Vegetation, Sonoran Desert, Arizona. Masters Thesis. Division of Earth and Ocean Sciences, Duke University, Durham, NC, USA

Goldman DE and Turner RM. 1986. Vegetation change and plant demography in permanent plots in the Sonoran Desert. Ecology 67:695-712

Guyer C, Birkhead R, and Balbach H. 2006. Effects of Tracked-Vehicle Training Activity on Gopher Tortoise (Gopherus polyphemus) Behavior at Fort Benning, GA. Technical Report, 01 Dec 06. ERDC/CERL, Champaign, IL, Report Number ERDC/CERL TR-06-10

Hamerlynck EP, McAuliffe JR, McDonald EV, et al. 2002. Ecological responses of two Mojave desert shrubs to soil horizon development and soil water dynamics. Ecology 83(3):768-79 


\section{Yuma Proving Ground: Ecological Risk Assessment for Tracked Vehicles}

Haugen LB, Ayers PD, and Anderson AB. 2003. Vehicle movement patterns and vegetative impacts during military training exercises. J Terramech 40(2):83-95

Hershfield DM. 1961. Rainfall Frequency Atlas of the United States for durations from 30 minutes to 24 hours and return periods from 1 to 100 years. U.S. Department of Commerce, Weather Bureau Technical Paper No. 40, as cited in Ayres Associates 1996

Huxman TE, Wilcox BP, Breshears DD, et al. 2005. Ecohydrological implications of woody plant encroachment. Ecology 86:308-319

Jones DS, Efroymson RA, Suter II GW, et al. 2008. The Apache Longbow-Hellfire missile test at Yuma Proving Ground: Ecological risk assessment for missile firing. Hum Ecol Risk Assess (this issue)

Kade A and Warren SD. 2002. Soil and plant recovery after historic military disturbances in the Sonoran Desert, USA. Arid Land Res Manage 16(3):231-43

Lathrop EW. 1993. Recovery of perennial vegetation in military maneuver areas, In: Webb RH and Wilshire HG (eds), Environmental Effects of Off-road Vehicles. Impacts and Management in Arid Regions, pp 265-277. Springer-Verlag, New York, NY, USA

Leis SA, Leslie Jr DM, Engle DM, et al. 2007. Small mammals as indicators of short-term and long-term disturbance in mixed prairie. Environ Monitor and Assess 137:75-84

Ludwig JA, Wilcox BP, Breshears DD, et al. 2005. Vegetation patches and runoff-erosion as interacting ecohydrological processes in semiarid landscapes. Ecology 86(2):288-97

McAuliffe JR. 1994. Landscape evolution, soil formation, and ecological patterns and processes in Sonoran Desert bajadas, Ecol Monographs 64:111-48

McAuliffe JR. 2007. Desert Soils. Arizona-Sonora Desert Museum. Available at http://www.desertmuseum.org/books/nhsd_desert_soils.php. Accessed 8/26/2007

McDonald E. 2000. Developing effective ecosystem monitoring strategies for military activities in deserts: Preliminary results from Yuma Proving Ground. Partners in Environmental Technology Technical Symposium and Workshop, November 28-30, 2000, Alexandria, VA, USA. Poster 61 Abstract

McDonald EV, Pierson FB, Flerchinger GN, et al. 1996. Application of a soil-water balance model to evaluate the influence of Holocene climate change on calcic soils, Mojave Desert, California, USA. Geoderma 74:167-92

Musick HB. 1975. Barrenness of desert pavement in Yuma County, Arizona. Arizona-Nevada Academy of Sciences Journal 10:24-8, as cited in Ayres Associates 1996

Prose DV. 1985. Persisting effects of armored military maneuvers on some soils of the Mojave Desert. Environ Geol Water Sci 7(3):163-70

Prosser CW, Sedivec KK, and Barker WT. 2000. Tracked vehicle effects on vegetation and soil characteristics. J Range Manage 53:666-70

Schlesinger WH and Jones CS. 1984. The comparative importance of overland runoff and mean annual rainfall to shrub communities of the Mojave Desert. Bot Gaz 145:116-24

Schlesinger WH, Fonteyn PJ, and Reiners WA. 1989. Effects of overland flow on plant water relations, erosion, and soil water percolation on a Mojave Desert landscape. Soil Sci Soc Am J 53:1567-72

Schmitz OJ. 1992. Optimal diet selection by white-tailed deer: Balancing reproduction with starvation risk. Evol Ecol 6:125-41

Severinghaus WD and Severinghaus MC. 1982. Effects of tracked vehicle activity on bird populations. J Environ Manage. 6:163-9

Stromberg JC, Bagstad KJ, Leenhouts JM, et al. 2005. Effects of stream flow intermittency on riparian vegetation of a semiarid region river (San Pedro River, Arizona). J River Res and Appl 21(8):925-938

Suter II GW, Reinbold KA, Rose WH, et al. 2002. Military Ecological Risk Assessment Framework (MERAF) for Assessment of Risks of Military Training and Testing to Natural Resources. ORNL/TM-2002/295. Oak Ridge National Laboratory, Oak Ridge, TN, USA 


\section{J. Peterson et al.}

USACOE (US Army Corps of Engineers). 1990. HEC-1 Flood Hydrograph Package, Users Manual, as cited in Ayres Associates 1996

USAEC (US Army Environmental Center). 1999. U.S. Army Training and Testing Area Carrying Capacity (ATTACC). Handbook for Installations. Version 1.1. Aberdeen Proving Ground, MD, USA

USEPA (US Environmental Protection Agency). 1998. Guidelines for Ecological Risk Assessment. EPA/630/R-95/002F. Risk Assessment Forum, Washington, DC, USA

Watts SE. 1998. Short-term influence of tank tracks on vegetation and microphytic crusts in shrubsteppe habitat. Environ Manage 22(4):611-6

Wilson SD. 1988. The effects of military tank traffic on prairie-A management model. Environ Manage 12(3):397-403

YPG (US Army Yuma Proving Ground). 2001. Final Range Wide Environmental Impact Statement, prepared by Gutierrez-Palmenberg, Inc., Yuma Proving Ground, Yuma, AZ, USA 
Copyright of Human \& Ecological Risk Assessment is the property of Taylor \& Francis Ltd and its content may not be copied or emailed to multiple sites or posted to a listserv without the copyright holder's express written permission. However, users may print, download, or email articles for individual use. 